\title{
Effect of Chitosan Solution on the Inhibition of Pseudomonas fluorescens Causing Bacterial Head Rot of Broccoli
}

\author{
Bin Li ${ }^{1}$, Baoping Liu', Ting Su${ }^{1}$, Yuan Fang ${ }^{1}$, Guanlin Xie ${ }^{1 *}$, Guofen Wang ${ }^{2}$, Yanli Wang ${ }^{3}$ and Guochang Sun ${ }^{3 *}$ \\ ${ }^{1}$ State Key Laboratory of Rice Biology, Key Laboratory of Molecular Biology of Crop Pathogens and Insects, Ministry of \\ Agriculture, Institute of Biotechnology, Zhejiang University, Hangzhou 310029, China \\ ${ }^{2}$ Institute of Environmental and Plant Protection, Chinese Academy of Tropical Agricultural Sciences, Danzhou 571737, China \\ ${ }^{3}$ Zhejiang Academy of Agricultural Sciences, Hangzhou 310021, China \\ (Received on December 25, 2009; Accepted on April 4, 2010)
}

The in vitro antibacterial properties of two kinds of chitosan solutions and their effect in protection of broccoli from bacterial head rot disease were evaluated. Results showed that the two kinds of chitosan solution at different concentrations exhibited strong antibacterial activity against Pseudomonas fluorescens. However, the antibacterial activity of chitosan A solution increased with the increase of chitosan concentration up to 0.10 $\mathrm{mg} / \mathrm{ml}$ while the antibacterial activity of chitosan $B$ solution increased with the increase of chitosan concentration up to $0.05 \mathrm{mg} / \mathrm{ml}$. In addition, the antibacterial activity of chitosan $A$ and chitosan $B$ solution of 0.10 $\mathrm{mg} / \mathrm{ml}$ increased with the incubation time within $12 \mathrm{~h}$ and $24 \mathrm{~h}$, respectively. The disease incidence and the lesion diameter of broccoli inoculated with $\boldsymbol{P}$. fluorescens were significantly reduced when plants were either pretreated or post-treated with six different combinations of chitosan solutions. Overall, the results indicated that the two kinds of chitosan solutions had a potential in controlling bacterial head rot of broccoli.

Keywords : antibacterial activity, bacterial head rot, broccoli, chitosan, Pseudomonas fluorescens

Broccoli (Brassica oleracea L. var. italica) is one of the many important economic crops grown in the world and has been marketed as a nutritious dietary supplement due to its high fiber, vitamin $\mathrm{C}$, vitamin $\mathrm{A}$ and mineral content including calcium and iron (Vasanthi et al., 2009; Wang et al., 2008). In China, planted acreage of broccoli has been increasing in recent years and, in 2007 , over 20,000 hectares were grown, of which around 60 percent were mainly

\footnotetext{
*Co-Corresponding authors.

Guanlin Xie

Phone) +86-571-86971412, FAX) +86-571-86971680

E-mail)glxie@zju.edu.cn

Guochang Sun

Phone) +86-571- 86404073, FAX) +86-571- 86404225

E-mail)sungc@zaas.org
}

exported to Japan, Korea, Malaysia and Canada (Su, 2008). However, bacterial head rot has been recently observed on broccoli in China and the causal bacterium was attributed to Pseudomonas fluorescens (Li et al., 2009a). Broccoli production in China has been seriously hampered by the disease, which reduced the quality and marketability of broccoli. In severe cases, the incidence of disease was between $65 \%$ and $81 \%$ in some fields (Li et al., 2009a). In addition, this disease has been reported in many other countries, which lead to crops losses of between $30 \%$ and $100 \%$ in some fields (Cui and Harling, 2006; Darling et al., 2000; Hildebrand, 1989). However, there are very few bactericidal chemicals available for controlling this disease and most of them are copper formulations with limited effectiveness (Pajot and Silué, 2005). Therefore, new measures should been developed to prevent the infection and further spread of the disease.

Some biochemicals in particular chitosan have been attempted to control plant disease (Bell et al., 1998; BenShalom and Fallik, 2003). Treating tomato plants with chitosan solution reduced mycelial growth, sporangial production, and release of zoospores and germination of cysts of Phytophthora infestans which resulted in significant disease protection (Atia et al., 2005). Furthermore, chitosan seed treatment could reduce Colletotrichum sp. infection and improve performance of chili seedling (Photchanachai et al., 2006). In addition, Li et al. (2008b) found that chitosan solution has strong in vitro antibacterial activity against Xanthomonas strains that cause leaf spot disease of Euphorbia pulcherrima. Interestingly, the effects of chitosan as an antimicrobial preservative for fruit, vegetables and food have also been evaluated (Devlieghere et al., 2004; Fujimoto et al., 2006). However, few investigations have been generated about inhibitory ability of chitosan on bacterial diseases in broccoli. The objective of this research was to evaluate the antibacterial activity of two kinds of chitosan solutions against the $P$. fluorescens pathogen that causing head rot disease of broccoli under different environments. 
Preparation of chitosan stock. Chitosan (degree of Ndeacetylation no less than $85 \%$, practical grade, from crab shells) and chitosan (degree of N-deacetylation 75\%, from crab shells) were obtained from Sigma-Aldrich (USA) and named as chitosan A and chitosan B, respectively. Stock solution of chitosan A or chitosan B $(5 \mathrm{mg} / \mathrm{ml})$ was prepared in $1 \%$ acetic acid with $\mathrm{pH}$ being adjusted to 6.0 with $\mathrm{NaOH}$ (Li et al., 2008b). After stirring (160 rpm) for $24 \mathrm{~h}$ at room temperature, the stock solution was autoclaved at $121{ }^{\circ} \mathrm{C}$ for $20 \mathrm{~min}$. Sterile deionized water of $\mathrm{pH} 6.0$ was used as a control.

Cultivation of bacteria. The virulent strain PFB-01 of $P$. fluorescens was isolated from diseased broccoli in Zhejiang province and deposited in the culture collection of the Institute of Biotechnology, Zhejiang University, China. The bacterial strain was cultured for $48 \mathrm{~h}$ on nutrient agar medium (Fang et al., 2009; Li et al., 2008a) at $28^{\circ} \mathrm{C}$. After incubation, bacterial suspension was prepared in sterilized water, and the initial concentration of bacteria was adjusted to approximately $10^{9}$ colony forming units (CFU)/ml.

Counting surviving cells. Bacterial suspensions were tenfold serially diluted and $10 \mu \mathrm{l}$ samples were inoculated on nutrient agar medium in hexaplicate for each dilution and were incubated for $48 \mathrm{~h}$ at $28^{\circ} \mathrm{C}$. After incubation, the surviving cells on the agar were counted based on the colony forming units and then the mean value of the cells at the lowest dilution was calculated. Each experiment was carried out in duplicate and was replicated twice.

Statistical analysis. The software STATGRAPHICS Plus, version 4.0 (Copyright Manugistics Inc., Rockville, Md., USA) was used to perform the statistical analysis. Levels of significance $(p<0.05)$ of main treatments and their interactions were calculated by analysis of variance after testing for normality and variance homogeneity.

Effect of chitosan concentration on the antibacterial activity. Chitosan solutions of $5 \mathrm{ml}$ in volume were prepared by adding chitosan stock to sterile deionized water to give a final chitosan concentration of $0.01,0.05$ and 0.10 $\mathrm{mg} / \mathrm{ml}$. Bacterial solution was added to $5 \mathrm{ml}$ of chitosan solution to give a final bacterial concentration of $10^{8} \mathrm{CFU} /$ $\mathrm{ml}$ and then the mixture was incubated at $28^{\circ} \mathrm{C}$ on a rotary shaker (Hualida Company, China) at $160 \mathrm{rpm}$. In the control treatment chitosan stock was replaced with sterile deionized water of $\mathrm{pH} 6.0$ in order to obtain the same $\mathrm{pH}$. Two hours later, samples were collected from each cell suspension and bacterial counting was followed as indicated above. The surviving cell numbers in chitosan A solution of $0.01 \mathrm{mg} / \mathrm{ml}$ decreased $0.73 \mathrm{Log} \mathrm{CFU} / \mathrm{ml}$ while the surviving
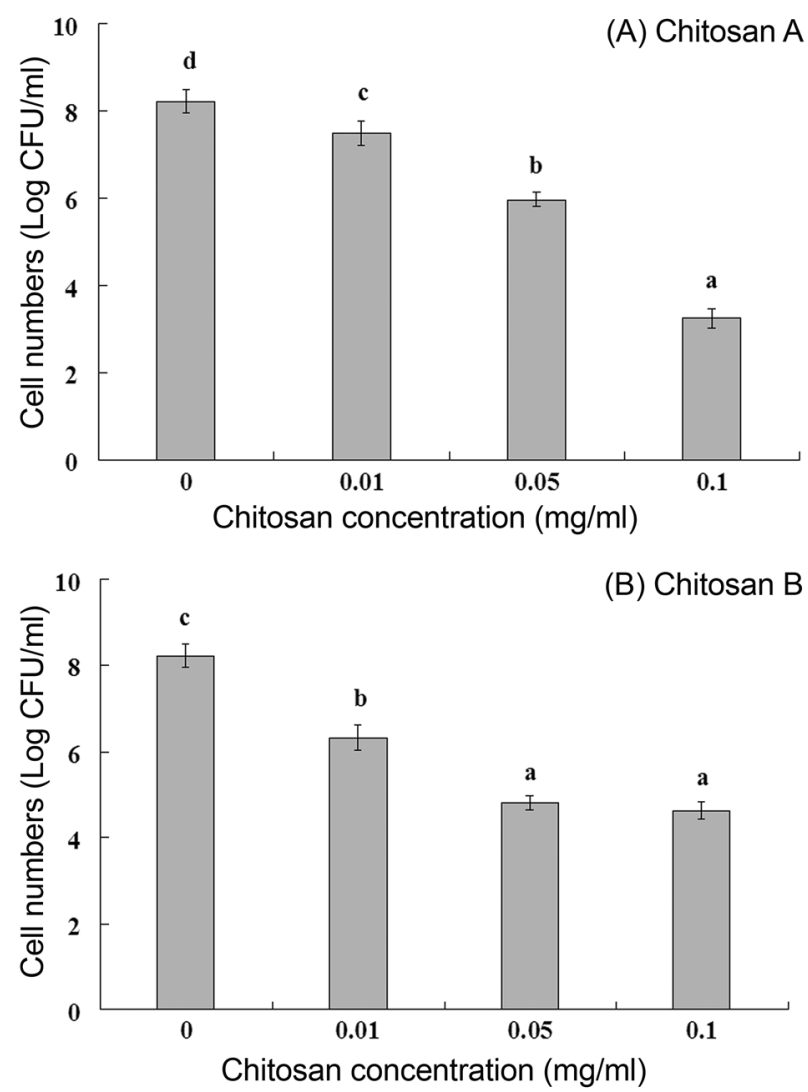

Fig. 1. Effect of chitosan concentration on the antibacterial activity of Pseudomonas fluorescens strain PFB-01. (A) Chitosan A; (B) Chitosan B. Initial concentration of bacteria is approximately $10^{8} \mathrm{CFU} / \mathrm{ml}$. Columns with the same letters are not significantly different $(p<0.05)$. Error bars represent the standard error of the mean $(n=6)$. Data are from a representative experiment repeated twice with similar results.

cell numbers in chitosan A solution of $0.10 \mathrm{mg} / \mathrm{ml}$ decreased $4.98 \mathrm{Log} \mathrm{CFU} / \mathrm{ml}$ compared to the control (Fig. 1A). However, the surviving cell numbers in chitosan B solution of $0.01 \mathrm{mg} / \mathrm{ml}$ decreased $1.90 \mathrm{Log} \mathrm{CFU} / \mathrm{ml}$ while the surviving cell numbers in chitosan B solution of $0.05 \mathrm{mg} / \mathrm{ml}$ decreased 3.42 Log CFU/ml compared to the control (Fig. 1B). Concentrations higher than $0.05 \mathrm{mg} / \mathrm{ml}$ were not significantly different (Fig. 1B).

Both chitosan A and chitosan B at three different concentrations showed effective antibacterial activity against $P$. fluorescens strain PFB-01 compared to the control after $2 \mathrm{~h}$ of incubation (Fig. 1A, 1B). Although P. fluorescens have long been identified as biological control agents (Cho et al., 2009; Choi et al., 2006; Ipper et al., 2005; Kong et al., 2009), several studies revealed that $P$. fluorescens has wide range under natural field infection (Cui and Harling, 2006; Lee et al., 2009; Li et al., 2009b; Saygili et al., 2004). Interestingly, this study indicated that the two kinds of chitosan solutions at different concentrations had strong 
antibacterial activity against the pathogenic $P$. fluorescens compared to the control. Therefore, application of chitosan seems to be a promising method to inhibit the strains of $P$. fluorescens from different host plants. In addition, in agreement with the result of $\mathrm{Li}$ et al. (2008b), this result indicated that the antibacterial activity of chitosan $\mathrm{A}$ and chitosan B against P. fluorescens was influenced by its concentration in the solution. However, the antibacterial activity of chitosan A solution increased with the increase of chitosan concentration up to $0.10 \mathrm{mg} / \mathrm{ml}$ while the antibacterial activity of chitosan $B$ solution increased with the increase of chitosan concentration up to $0.05 \mathrm{mg} / \mathrm{ml}$. This difference may be ascribed to the composition of chitosan, which is consistent with the result of Seyfarth et al. (2008), who found that the antifungal activity of chitosan depend on degree of deacetylation and molecular weight.

Effect of incubation time on the antibacterial activity. Chitosan solutions of $5 \mathrm{ml}$ in volume were prepared by adding $100 \mu \mathrm{l}$ chitosan stock to $4.90 \mathrm{ml}$ sterile deionized water to give a final chitosan concentration of $0.10 \mathrm{mg} / \mathrm{ml}$. $P$. fluorescens strain PFB-01 was inoculated into chitosan solution as indicated above. In the control treatment, chitosan stock was replaced with sterile deionized water of $\mathrm{pH}$ 6.0 in order to obtain the same $\mathrm{pH}$. Antibacterial activity of chitosan solution on the growth of $P$. fluorescens was determined after $0,2,4,6,12$ and $24 \mathrm{~h}$ of incubation, respectively. This result indicated that in the absence of chitosan, the surviving cell numbers in sterile deionized water decreased $0.20 \mathrm{Log} \mathrm{CFU} / \mathrm{ml}$ after $2 \mathrm{~h}$ of incubation compared to the starting value. With the increase in incubation time, the surviving cell numbers remain stable (Table 1). In the presence of chitosan A or chitosan B, the

Table 1. Effect of incubation time on the antibacterial activity of chitosan solution against Pseudomonas fluorescens strain PFB$01^{\mathrm{a}}$

\begin{tabular}{cccc}
\hline \hline \multirow{2}{*}{$\begin{array}{c}\text { Incubation } \\
\text { time (h) }\end{array}$} & \multicolumn{3}{c}{ Cell numbers $\left(\log _{10} \mathrm{CFU} / \mathrm{ml}\right)$} \\
\cline { 2 - 4 } & Control & ${\text { Chitosan } \mathrm{A}^{\mathrm{b}}}^{\text {Chitosan B }}$ \\
\hline 0 & $8.60 \pm 0.19 \mathrm{~b}^{\mathrm{c}}$ & $8.60 \pm 0.19 \mathrm{~d}$ & $8.60 \pm 0.19 \mathrm{e}$ \\
2 & $8.40 \pm 0.25 \mathrm{ab}$ & $4.17 \pm 0.29 \mathrm{c}$ & $6.00 \pm 0.14 \mathrm{~d}$ \\
4 & $8.43 \pm 0.28 \mathrm{ab}$ & $3.70 \pm 0.10 \mathrm{~b}$ & $5.70 \pm 0.15 \mathrm{c}$ \\
6 & $8.36 \pm 0.23 \mathrm{ab}$ & $3.76 \pm 0.21 \mathrm{~b}$ & $5.48 \pm 0.16 \mathrm{~b}$ \\
12 & $8.44 \pm 0.14 \mathrm{ab}$ & $3.05 \pm 0.12 \mathrm{a}$ & $5.31 \pm 0.17 \mathrm{~b}$ \\
24 & $8.25 \pm 0.20 \mathrm{a}$ & $4.27 \pm 0.14 \mathrm{c}$ & $4.95 \pm 0.13 \mathrm{a}$ \\
\hline
\end{tabular}

${ }^{a}$ Initial concentration of bacteria is approximately $10^{8} \mathrm{CFU} / \mathrm{ml}$.

${ }^{\mathrm{b}}$ Concentration of chitosan solution is $0.10 \mathrm{mg} / \mathrm{ml}$.

${ }^{c}$ The data are shown as means \pm standard error from a representative experiment repeated twice with similar results $(n=6)$. Means in a column followed by the same letter are not significantly different $(p<0.05)$. surviving cell numbers were significantly decreased compared to the starting value (Table 1 ). After $2 \mathrm{~h}$ of incubation, the surviving cell numbers in the chitosan A solution decreased 4.43 Log CFU/ml while the surviving cell numbers in the chitosan B solution decreased 2.60 Log CFU/ml compared to the control (Table 1). However, the surviving cell numbers in the chitosan A solution decreased 5.55 Log $\mathrm{CFU} / \mathrm{ml}$ while the surviving cell numbers in the chitosan B solution decreased 3.29 Log $\mathrm{CFU} / \mathrm{ml}$ compared to the control after $12 \mathrm{~h}$ of incubation (Table 1). Result from this study indicated that the antibacterial activity of both chitosan A and chitosan B solution were affected by the incubation time, which is consistent with the result of $\mathrm{Li}$ et al. (2008b), who found that a certain incubation time is required for the chitosan solution to inhibit the bacterial growth. However, the antibacterial activity of chitosan A solution of $0.10 \mathrm{mg} / \mathrm{ml}$ increased with the incubation time within $12 \mathrm{~h}$ while the antibacterial activity of chitosan B solution of $0.10 \mathrm{mg} / \mathrm{ml}$ increased with the incubation time within $24 \mathrm{~h}$.

Effect of chitosan pre-treatment and post-treatment on head rot disease of broccoli. A bioassay was used to determine the ability of chitosan to suppress the incidence and severity of bacterial head rot disease of broccoli during growth and storage. Healthy heads of pre-harvested broccoli (cultivar Sijilv) were treated with either the bactericide (Zinc thiazole) or chitosan solutions before and after pathogen inoculation. Bacteria was cultured in nutrient broth and adjusted to $10^{8} \mathrm{CFU} / \mathrm{ml}$. Heads of broccoli was inoculated using a $100 \mu \mathrm{l}$ tip dipped in a $50 \mu \mathrm{l}$ suspension of $P$. fluorescens strain PFB-01. Six different combinations of chitosan solutions were applied in this study, which included chitosan $\mathrm{A}$ at 0.05 and $0.10 \mathrm{mg} / \mathrm{ml}$, chitosan $\mathrm{B}$ at 0.05 and $0.10 \mathrm{mg} / \mathrm{ml}$, chitosan $\mathrm{A}+\mathrm{B}$ at 0.05 and $0.10 \mathrm{mg} / \mathrm{ml}$. The bactericide $(100 \mu \mathrm{g} / \mathrm{ml})$ or six different combinations of chitosan solutions were sprayed until runoff onto the heads. Control plants were sprayed with distilled water. Each treatment had three plants. Infiltrated plants were incubated in a growth chamber at $28{ }^{\circ} \mathrm{C}$ and $90 \%$ relative humidity with $16 \mathrm{~h}$ of light and $8 \mathrm{~h}$ of dark. Ten inoculation sites per plant were used for scoring of disease symptoms. One week after inoculation, the disease incidence and the average radius of the lesion were observed and scored.

The heads of broccoli inoculated with the pathogen alone resulted in $83.3 \%$ and $76.7 \%$ disease incidence in pretreatment and post-treatment of chitosan, respectively (Table 2 ), while the average diameter of the lesion was $6.1 \mathrm{~mm}$ and $5.4 \mathrm{~mm}$, respectively (Table 3 ). However, the disease incidence and the lesion diameter of broccoli heads inoculated with $P$. fluorescens were significantly reduced when plants were either pre-treated or post-treated with six 
Table 2. Effect of chitosan pre-treatment and post-treatment on the disease incidence of broccoli heads inoculated with Pseudomonas fluorescens strain PFB-0 $1^{\text {a }}$

\begin{tabular}{lcc}
\hline \hline \multirow{2}{*}{ Treatments } & \multicolumn{2}{c}{ Disease incidence $(\%)$} \\
\cline { 2 - 3 } & Pre-treatment & Post-treatment \\
\hline Pathogen control & $83.3 \mathrm{~g}^{\mathrm{c}}$ & $76.7 \mathrm{e}$ \\
Chitosan A $(0.05 \mathrm{mg} / \mathrm{ml})$ & $30.0 \mathrm{~cd}$ & $43.3 \mathrm{bcd}$ \\
Chitosan A $(0.10 \mathrm{mg} / \mathrm{ml})$ & $16.7 \mathrm{~b}$ & $33.3 \mathrm{~b}$ \\
Chitosan B $(0.05 \mathrm{mg} / \mathrm{ml})$ & $50.0 \mathrm{ef}$ & $53.3 \mathrm{~d}$ \\
Chitosan B $(0.10 \mathrm{mg} / \mathrm{ml})$ & $53.3 \mathrm{f}$ & $46.7 \mathrm{~cd}$ \\
Chitosan A + B $(0.05 \mathrm{mg} / \mathrm{ml})$ & $23.3 \mathrm{bc}$ & $36.7 \mathrm{bc}$ \\
Chitosan A + B $(0.10 \mathrm{mg} / \mathrm{ml})$ & $50.0 \mathrm{ef}$ & $50.0 \mathrm{~d}$ \\
Bactericide $($ Zinc thiazole) & $40.0 \mathrm{de}$ & $36.7 \mathrm{bc}$ \\
None & $0.0 \mathrm{a}$ & $0.0 \mathrm{a}$ \\
\hline
\end{tabular}

${ }^{\mathrm{a}}$ The inoculum concentration of bacteria is approximately $10^{8} \mathrm{CFU} / \mathrm{ml}$.

${ }^{\mathrm{b}}$ The concentration of the bactericide is $100 \mu \mathrm{g} / \mathrm{ml}$.

${ }^{\circ}$ Data are from a representative experiment repeated twice with similar results. Means in a column followed by the same letter are not significantly different $(p<0.05)$.

Table 3. Effect of chitosan pre-treatment and post-treatment on the lesion diameter of broccoli heads inoculated with Pseudomonas fluorescens strain PFB-01 ${ }^{\mathrm{a}}$

\begin{tabular}{lcc}
\hline \hline \multirow{2}{*}{ Treatments } & \multicolumn{2}{c}{ Lesion diameter $(\mathrm{mm})$} \\
\cline { 2 - 3 } & Pre-treatment & Post-treatment \\
\hline Pathogen control & $6.1 \mathrm{e}^{\mathrm{c}}$ & $5.4 \mathrm{~g}$ \\
Chitosan A $(0.05 \mathrm{mg} / \mathrm{ml})$ & $1.2 \mathrm{bc}$ & $2.2 \mathrm{cde}$ \\
Chitosan A $(0.10 \mathrm{mg} / \mathrm{ml})$ & $0.4 \mathrm{ab}$ & $1.3 \mathrm{~b}$ \\
Chitosan B $(0.05 \mathrm{mg} / \mathrm{ml})$ & $2.8 \mathrm{~d}$ & $3.2 \mathrm{f}$ \\
Chitosan B $(0.10 \mathrm{mg} / \mathrm{ml})$ & $2.5 \mathrm{~d}$ & $2.6 \mathrm{ef}$ \\
Chitosan A + B $(0.05 \mathrm{mg} / \mathrm{ml})$ & $1.0 \mathrm{abc}$ & $1.4 \mathrm{bc}$ \\
Chitosan A + B $(0.10 \mathrm{mg} / \mathrm{ml})$ & $1.9 \mathrm{~cd}$ & $2.3 \mathrm{de}$ \\
Bactericide $(\text { Zinc thiazole })^{\mathrm{b}}$ & $1.7 \mathrm{~cd}$ & $1.7 \mathrm{bcd}$ \\
None & $0.0 \mathrm{a}$ & $0.0 \mathrm{a}$ \\
\hline
\end{tabular}

${ }^{\mathrm{a}}$ The inoculum concentration of bacteria is approximately $10^{8} \mathrm{CFU} / \mathrm{ml}$.

${ }^{\mathrm{b}}$ The concentration of the bactericide is $100 \mu \mathrm{g} / \mathrm{ml}$.

${ }^{\circ}$ Data are from a representative experiment repeated twice with similar results. Means in a column followed by the same letter are not significantly different $(p<0.05)$.

different combinations of chitosan solutions compared to the respective control (Table 2, 3). In pre-treatment of chitosan, there was no significant difference in disease incidence between three different chitosan solutions (A at $0.05 \mathrm{mg} / \mathrm{ml}, \mathrm{B}$ at $0.05 \mathrm{mg} / \mathrm{ml}, \mathrm{A}+\mathrm{B}$ at $0.10 \mathrm{mg} / \mathrm{ml}$ ) and the bactericide, while two chitosan solutions (A at 0.10 $\mathrm{mg} / \mathrm{ml}, \mathrm{A}+\mathrm{B}$ at $0.05 \mathrm{mg} / \mathrm{ml}$ ) and one chitosan solution (B at $0.10 \mathrm{mg} / \mathrm{ml}$ ) reduced and increased the disease incidence, respectively, compared to the bactericide (Table 2). In addition, there was no significant difference in lesion diameter between five different chitosan solutions (A at $0.05 \mathrm{mg} / \mathrm{ml}$,
B at 0.05 and $0.10 \mathrm{mg} / \mathrm{ml}, \mathrm{A}+\mathrm{B}$ at 0.05 and $0.10 \mathrm{mg} / \mathrm{ml})$ and the bactericide, while one chitosan solutions (A at 0.10 $\mathrm{mg} / \mathrm{ml}$ ) reduced the lesion diameter compared to the bactericide (Table 3). In post-treatment of chitosan, there was no significant difference in disease incidence between four different chitosan solutions (A at 0.05 and $0.10 \mathrm{mg} / \mathrm{ml}$, $\mathrm{B}$ at $0.10 \mathrm{mg} / \mathrm{ml}, \mathrm{A}+\mathrm{B}$ at $0.05 \mathrm{mg} / \mathrm{ml})$ and the bactericide, while two chitosan solutions (B at $0.05 \mathrm{mg} / \mathrm{ml}, \mathrm{A}+\mathrm{B}$ at $0.10 \mathrm{mg} / \mathrm{ml}$ ) increased the disease incidence compared to the bactericide (Table 2). In addition, there was no significant difference in lesion diameter between four different chitosan solutions (A at 0.05 and $0.10 \mathrm{mg} / \mathrm{ml}, \mathrm{A}+\mathrm{B}$ at 0.05 and $0.10 \mathrm{mg} / \mathrm{ml}$ ) and the bactericide, while two chitosan solutions (B at 0.05 and $0.10 \mathrm{mg} / \mathrm{ml}$ ) increased the lesion diameter compared to the bactericide (Table 3). Broccoli heads uninoculated with $P$. fluorescens strain PFB-01 were free of symptoms.

In agreement with in vitro experiment results, both pretreatment and post-treatment of plants with different combinations of the two kinds of chitosan solutions significantly reduced the disease incidence and the lesion diameter of broccoli heads compared to the control, which can be attributed, at least in part, to the direct antibacterial activity of chitosan solution. However, in general, the disease incidence and the lesion diameter were more reduced by the pre-treatment than the post-treatment of plants with chitosan solutions. In particular, plants pre-treated with chitosan A solution at $0.10 \mathrm{mg} / \mathrm{ml}$ showed more reduction on the disease incidence and the lesion diameter than that of the bactericide. Therefore, chitosan A coating seems to be a promising method to prevent the disease from broccoli heads.

Overall, our results clearly demonstrate that the two kinds of chitosan solutions have strong antibacterial activity against P. fluorescens strain PFB-01 under various environmental conditions. To the best of our knowledge, this is the first report about antibacterial activities of chitosan on the pathogenic $P$. fluorescens. In addition, it is evident that the two kinds of chitosan solutions have a potential in the prevention and control of bacterial head rot disease of broccoli. Considering the absence of any sort of remedial measures for bacterial head rots disease of broccoli the present investigation may prove helpful in a field which is largely dominated by economically handicapped broccoli growers.

\section{Acknowledgements}

This project was supported by Zhejiang Provincial Natural Science Foundation of China (Y3090150), Science Foundation of Chinese University (KYJD09022), National Natural Science Foundation of China (30600475) and Specialized 
Research Fund for the Doctoral Program of Higher Education (20090101120083).

\section{References}

Atia, M. M. M., Buchenauer, H., Aly, A. Z. and Abou-Zaid, M. I. 2005. Antifungal activity of chitosan against Phytophthora infestans and activation of defence mechanisms in tomato to late blight. Biol. Agric. Hortic. 23:175-197.

Bell, A. A., Hubbard, J. C. and Li, L. 1998. Effects of chitin and chitosan on the incidence and severity of Fusarium yellows of celery. Plant Dis. 82:322-328.

Ben-Shalom, N. and Fallik, E. 2003. Further suppression of Botrytis cinerea disease in cucumber seedlings by chitosan-copper complex as compared with chitosan alone. Phytoparasitica 31:99-102.

Cho, S., Lee, S. H., Park, S., Choi, K. U., Cho, J., Hur, J. H., Shrestha, A. and Lim, C. 2009. Identification of a genetic locus related to antivirus production in Pseudomonas fluorescence strain Gpf01 against cucumber mosaic virus. Plant Pathol. J. 25:77-85.

Choi, G J., Kim, J. C., Park, E. J., Choi, Y. H., Jang, K. S., Lim, H. K., Cho, K. Y. and Lee, S. W. 2006. Biological control activity of two isolates of Pseudomonas fluorescens against rice sheath blight. Plant Pathol. J. 22:289-294.

Cui, X. H. and Harling, R. 2006. Evaluation of bacterial antagonists for biological control of broccoli head rot caused by Pseudomonas fluorescens. Phytopathology 96:408-416.

Darling, D., Harling, R., Simpson, R. A., McRoberts, N. and Hunter, E. A. 2000. Susceptibility of broccoli cultivars to bacterial head rot: in vitro screening and the role of head morphology in resistance. Eur. J. Plant Pathol. 106:11-17.

Devlieghere, F., Vermeulen, A. and Debevere, J. 2004. Chitosan: antimicrobial activity, interactions with food components and applicability as a coating on fruit and vegetables. Food Microbiol. 21:703-714.

Fang, Y., Li, B., Wang, F., Liu, B. P., Wu, Z. Y., Su, T., Qiu, W. and Xie, G L. 2009. Bacterial fruit rot of apricot caused by Burkholderia cepacia in China. Plant Pathol. J. 25:429-432.

Fujimoto, T., Tsuchiya, Y., Terao, M., Nakamura, N. and Yamamoto, M. 2006. Antibacterial effects of chitosan solution ${ }^{\circledR}$ against Legionella pneumophila, Escherichia coli, and Staphylococcus aureus. Int. J. Food Microbiol. 112:96-101.

Hildebrand, P. D. 1989. Surfactant-like characteristics and identity of bacteria associated with broccoli head rot in Atlantic Canada. Can. J. Plant Pathol. 11:205-214.

Ipper, N. S., Kim, J. E., Koo, J. H., Hur, J. H. and Lim, C. K. 2005. Inhibitory effects of a Korean strain Gpf01 identified as
Pseudomonas fluorescens on cucumber mosaic virus. Plant Pathol. J. 21:262-269.

Kong, H. G., Choi, K. H., Heo, K. R., Lee, K. Y., Lee, H. J., Moon, B. J. and Lee, S. W. 2009. Generation of a constitutive green fluorescent protein expression construct to mark biocontrol bacteria using P43 promoter from Bacillus subtilis. Plant Pathol. J. 25:136-141.

Lee, Y. S., Han, H. S., Kim, G. H., Koh, Y. J., Hur, J. S. and Jung, J. S. 2009. Causal agents of blossom blight of Kiwifruit in Korea. Plant Pathol. J. 25:220-224.

Li, B., Wang, G. L., Wu, Z. Y., Qiu, W., Tang, Q. M. and Xie, G. L. 2009a. First report of bacterial head rot of broccoli caused by Pseudomonas fluorescens in China. Plant Dis. 93:1219.

Li, B., Wang, X., Chen, R. X., Huangfu, W. G and Xie, G. L. 2008b. Antibacterial activity of chitosan solution against Xanthomonas pathogenic bacteria isolated from Euphorbia pulcherrima. Carbohyd. Polym. 72:287-292.

Li, B., Xu, L. H., Lou, M. M., Li, F., Zhang, Y. D. and Xie, G L. 2008a. Isolation and characterization of antagonistic bacteria against bacterial leaf spot of Euphorbia pulcherrima. Lett. Appl. Microbiol. 46:450-455.

Li, B., Yu, R. R., Yu, S. H., Qiu, W., Fang, Y. and Xie, G L. 2009b. First report on bacterial heart rot of garlic caused by Pseudomonas fluorescens in China. Plant Pathol. J. 25:91-94.

Pajot, E. and Silué, D. 2005. Evidence that DL-3-aminobutyric acid and acibenzolar-S-methyl induce resistance against bacterial head rot disease of broccoli. Pest Manag. Sci. 61:11101114.

Photchanachai, S., Singkaew, J. and Thamthong, J. 2006. Effects of chitosan seed treatment on Colletotrichum sp. and seedling growth of chili cv. "Jinda". Acta Horticulturae 712:585-590.

Saygili, H., Aysan, Y., Sahin, F., Ustun, N. and Mirik, M. 2004. Occurrence of pith necrosis caused by Pseudomonas fluorescens on tomato plants in Turkey. Plant Pathol. 53:803.

Seyfarth, F., Schliemann, S., Elsner, P. and Hipler, U. C. 2008. Antifungal effect of high- and low-molecular-weight chitosan hydrochloride, carboxymethyl chitosan, chitosan oligosaccharide and $N$-acetyl-d-glucosamine against Candida albicans, Candida krusei and Candida glabrata. Int. J. Pharm. 353:139148.

$\mathrm{Su}$, Y. J. 2008. Spread and prospect of broccoli cultivar with high yield. Chin. Countryside Well-off Technol. 8:42-44.

Vasanthi, H. R., Mukherjee, S. and Das, D. K. 2009. Potential health benefits of broccoli- a chemico-biological overview. Mini Rev. Med. Chem. 9:749-759.

Wang, X. M., Cui, K. and Lu, Y. L. 2008. Overview of applicable value and production and export prospect of Chinese broccoli. Chin. Agri. Sci. Bull. 24:478-480. 